Proc. Indian Acad. Sci. (Earth Planet. Sci.), Vol. 105, No. 2, June 1996, pp. 157-171.

(C) Printed in India.

\title{
Evidence for the thrust emplacement of the 'Lesser Himalaya' Chur granite, Himachal Pradesh
}

\author{
DILIP K MUKHOPADHYAY, BIDYUT K BHADRA, \\ TAMAL K GHOSH and DEEPAK C SRIVASTAVA \\ Department of Earth Sciences, University of Roorkee, Roorkee 247667 , U.P., India
}

MS received 28 November 1995; revised 8 February 1996

\begin{abstract}
Numerous peraluminous and porphyritic granitic bodies and augen gneisses of granitic compositions occur in the nappe sequences of the Lower Himalaya. They are Proterozoic-to-lower Paleozoic in age and have been grouped into the 'Lesser Himalaya granite belt'. The mode of emplacement and tectonic significance of these granites are as yet uncertain but they are generally considered to be sheet-like intrusions into the surrounding rocks. The small and isolated granite body (the Chur granite) that crops out around the Chur peak in the Himachal Himalaya is one of the more famous of these granites. Several lines of evidence have been adduced to show that the Chur granite has a thrust (the Chur thrust) contact with the underlying metasedimentary sequence (locally called the Jutogh Group). The Chur granite with restricted occurrence at the highest topographic and structural levels represents an erosional remnant of a much larger sub-horizontal thrust sheet. The contact relations between the country rocks and many of the other granite and granitic augen gneisses in the Lesser Himalaya belt are apparently similar to that of the Chur granite suggesting that at least some of them may also represent thrust sheets.
\end{abstract}

Keywords. Granite; Lesser Himalaya; thrust; Himachal Pradesh.

\section{Introduction}

Within the Himalayan orogenic belt four longitudinally continuous and fault-bounded lithotectonic zones have traditionally been recognized (figure 1a; Gansser 1964; Le Fort 1975), viz., the High Himalaya Sedimentary Zone(HHSZ), the High Himalaya Crystalline Zone (HHCZ), the Lesser Himalaya Zone (LHZ) and the Sub-Himalaya Zone (SHZ). In the first three of these zones, numerous granitic bodies occur which have been grouped into three belts each running parallel to the orogen (Le Fort 1988). The granitic plutons of the northernmost 'North Himalaya belt' occur within the HHSZ. They are of two types: lower Paleozoic peraluminous porphyritic granites and two-mica adamellites of upper Tertiary age. The central 'High Himalaya belt' consists of about a dozen or so plutons and numerous sills and dykes of two-mica leucoadamellites which intrude both the $\mathrm{HHCZ}$ and $\mathrm{HHSZ}$ but close to the interface between them (i.e., South Tibet Detachment System, figure 1a). The plutons of the High Himalaya belt invariably yield Tertiary isotopic ages (e.g., Dietrich and Gansser 1981; Deniel et al 1987). The formation and intrusion of the leucogranitic bodies belonging to both the High and the North Himalaya belts have been related to the India-Eurasia collision and the subsequent evolution of the Himalayan crust (see Le Fort 1988 and references therein). In particular, it has been shown that the leucogranites of the High 


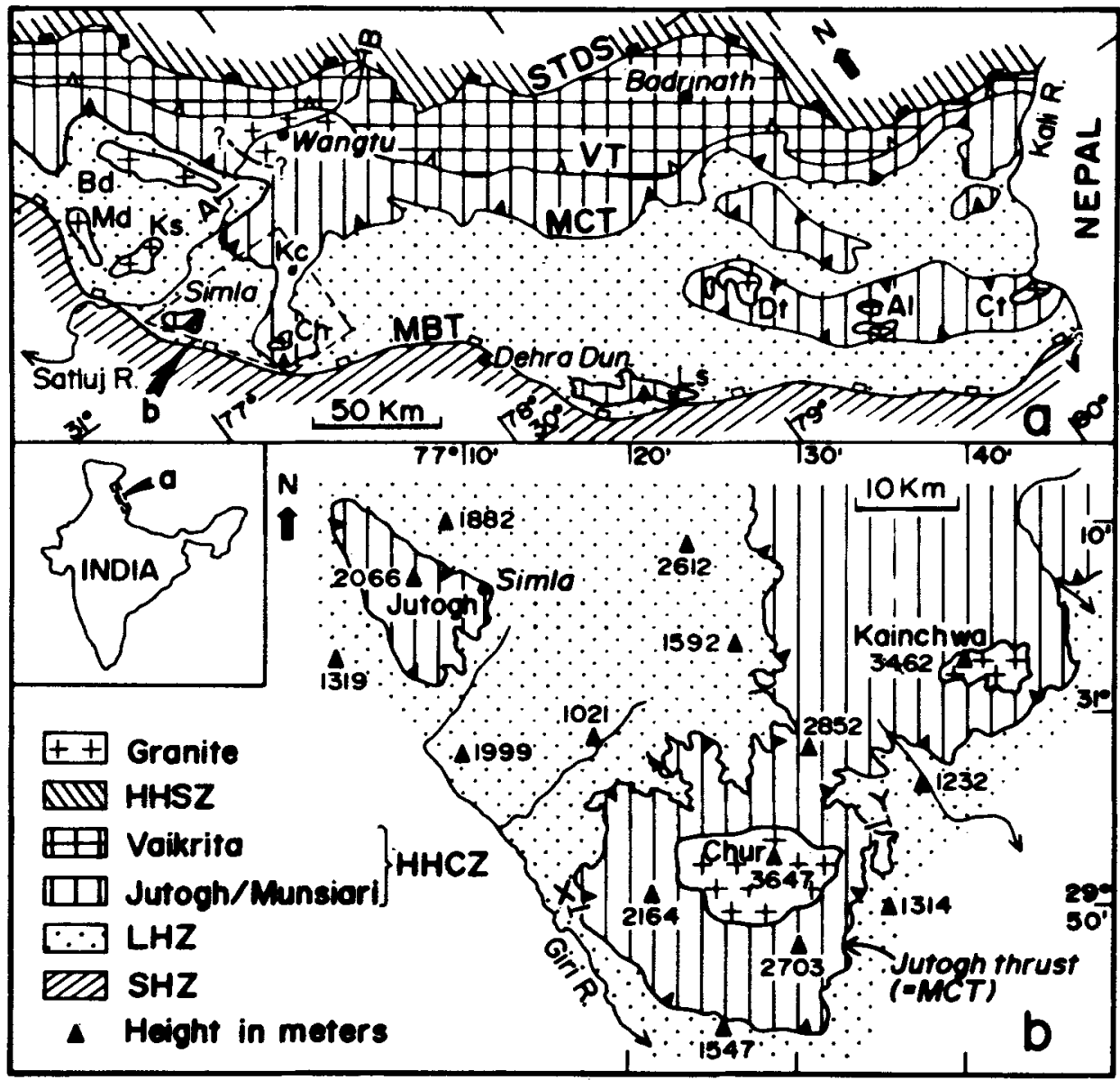

Figure 1. (a) Geological map of the Himachal-Garhwal Kumaun Himalaya showing the locations of Chur and some of the other 'Lesser Himalaya' granites (simplified from the compilations by Thakur 1983 and Paul 1990). Al: Almora; Bd: Bandal; Ch: Chur; Ct: Champawat; Dt: Dudatoli; Ks: Karsog; Ls: Lansdowne; Md: Mandi. Most of the other granites and granitic augen gneisses in this belt are too thin or too small in areal extent to be shown in this scale. (b) Geological map of the Simla-Chur peak-Kainchwa peak area (after Pilgrim and West 1928; Srikantia and Bhargava 1988). Cross section along X-Y is shown in figure 2.

Himalaya belt have formed by partial melting of the Himalayan crust during thrusting along the MCT (e.g., Dietrich and Gansser 1981; Le Fort 1981; Deniel et al 1987).

The Lesser Himalaya granite belt consists of a series of porphyritic peraluminous quartz-rich granite bodies which are somewhat akin to the lower Paleozoic granites of the North Himalaya belt. It is particularly well-marked in the physiographic Lower Himalaya of Himachal, Garhwal and Kumaun (figure 1a, Thakur 1983). Most of these granites are only a few $\mathrm{km}^{2}$ to a few tens of $\mathrm{km}^{2}$ in areal extent and are surrounded by the outcrops of the HHCZ and LHZ nappe sequences within short distances from the MCT. In addition, there are also a large number of thin sheet-like bodies of 'augen gneisses' of granitic composition in this belt (e.g., Pecher and Le Fort 1977; Valdiya 1980; 
Gururajan 1990). The isotopic ages of these granites vary from Proterozoic to early Paleozoic (e.g., Le Fort et al 1980; Scharer and Allegre 1983; Trivedi et al 1984) and, therefore, the magmatism that gave rise to the granitic rocks of this belt was unrelated to the Tertiary Himalayan orogeny.

The structural settings of these granites and the granitic augen gneisses are surprisingly still ambiguous. They are commonly mapped as rootless plutons that intruded the metamorphic country rocks exposed in the erosional outliers of the $\mathrm{HHCZ}$ (hanging wall of the MCT)(Chatterji and Swami Nath 1977; Valdiya 1980; Thakur 1983). This is important, because if these granites intruded the country rocks during the Proterozoicearly Paleozoic time then they have merely been transported to the present locations along with the nappe sequences and may not have much tectonic significance to the Tertiary Himalayan orogeny. Some workers (e.g., Sinha-Roy and Sengupta 1986), on the other hand, speculate that all the deformed granites in the LHZ are thrust wedges. If this postulation is correct then the Lesser Himalaya granites may have an important bearing on the overall geodynamic evolution of the Himalayan orogen. Unfortunately, the contact relations of these granitic bodies with the surrounding country rocks have. never been conclusively demonstrated.

The Lesser Himalaya granite occurring around the Chur peak in the Himachal Himalaya is one of the more famous of these bodies (the Chur granite, figure 1b). Pilgrim and West (1928) suggested that the Chur granite is a laccolithic intrusion from north into the surrounding metamorphic rocks. This view has been upheld by most of the later workers (Kanwar and Singh 1979; Kishore and Kanwar 1984). In this paper we present several lines of evidence to demonstrate that the Chur granite has a thrust relation with the underlying metasedimentary rocks of the $\mathrm{HHCZ}$ and discuss possible regional tectonic implications.

\section{The Chur granite}

\subsection{Geological setting}

In the northwestern Himalaya the frontal part of the $\mathrm{HHCZ}$ thrust sheet occurs in a series of klippen within the LHZ (figure 1a) and are collectively known as the outer crystalline belt (Thakur 1981). The Chur peak ( $3647 \mathrm{~m}$, also spelled as Chor or Chaur) is located at about $45 \mathrm{~km}$ SE of the Simla town in the outer crystalline belt of the Himachal Himalaya. Around the Chur peak the medium-grade metasedimentary rocks belonging to the HHCZ (locally called the Jutogh Group, Pilgrim and West 1928; Srikantia and Bhargava 1988) occur with an hour-glass type of outcrop pattern forming a half-klippe (figure 1b). The same Jutogh Group of rocks occur in a pearshaped klippe around Simla. The rocks of the Jutogh Group are underlain by the low-grade phyllites of the Chail Formation. The contact between them marks the Jutogh thrust which is supposedly a continuation of the MCT (Heim and Gansser 1939; Gansser 1964). The Chail Formation, in turn, is separated from the underlying sedimentary rocks of the $\mathrm{LHZ}$ along the Chail Thrust (Virdi 1979). The Chail Thrust sheet is considered to be the upper part of the LHZ (Fuchs 1981). In the Jutogh Group four distinct lithounits have been recognized, viz., lower carbonaceous schist, quartzite, upper carbonaceous schist and mica schist. The thin lower and upper carbonaceous schist units mark the Jutogh thrust (Pilgrim and West 1928; Naha and Ray 1971) 
and the Rajgarh thrust (Bhadra et al 1993: Mukhopadhyay et al 1994) respectively (figure 2). The isolated and approximately circular-shaped Chur granite body occurs within the Jutogh mica schist (figures 2 and 3).

\subsection{Topographic control}

The topography of the area around the the Chur peak is approximately like a dome with the highest altitudes around the Chur peak (figure $1 \mathrm{~b}$ ). The sedimentary rocks of the

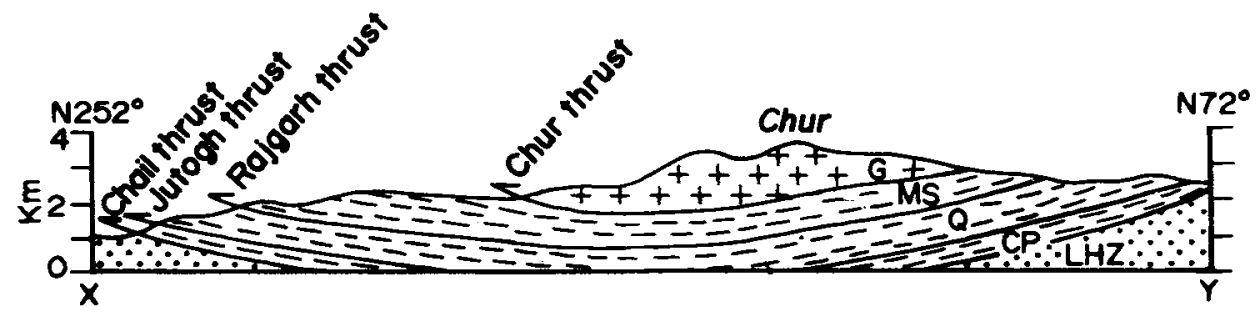

Figure 2. Structural cross section across Chur peak showing imbrication of sub-horizontal thrust sheets. G: Chur granite; MS: Jutogh mica schist; Q: Jutogh quartzite; CP: Chail phyllite; LHZ: sedimentary rocks of the Lesser Himalaya Zone.

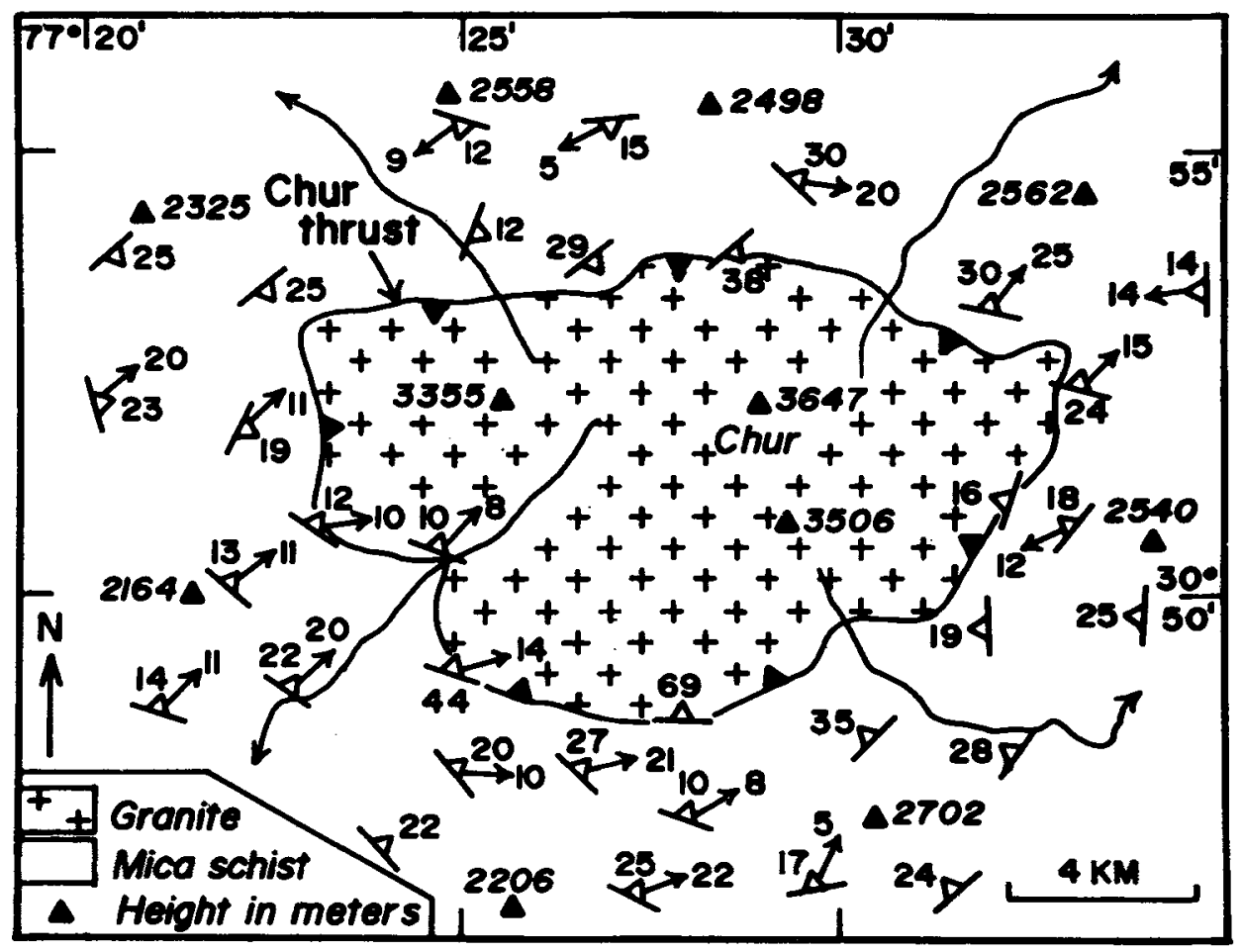

Figure 3. Structural map of the Chur granite showing gentle dip of foliations and the contact. The contact of the granite is modified after Pilgrim and West (1928). 
LHZ, the metasedimentary rocks of the Chail Formation and the Jutogh Group occur at successively higher topographic levels. The granite body is restricted at the highest topographic levels where the altitude exceeds about $3000 \mathrm{~m}$ (figures $1 \mathrm{~b}$ and 3 ). It also occurs at the highest structural levels in the sense that it overlies the topmost thrust sheet consisting of the Jutogh mica schist (figure 2). Around the Kainchwa peak (figure $1 \mathrm{~b}$ ) the topography is similar and a granite (the Kainchwa granite, Srikantia and Bhargava 1988) is exposed where altitudes exceed above $3000 \mathrm{~m}$. West and NE of the Kainchwa peak several hilltops with altitudes more than $3000 \mathrm{~m}$ are occupied by small granite bodies (figure 4). Towards NW around Jutogh peak near Simla the topography is similar. But in this area the maximum elevation is about $2000 \mathrm{~m}$ and there is no exposure of granitic rocks although the same Jutogh Group rocks are exposed (figure $1 \mathrm{~b}$ ). It is evident that the exposures of granite occur only when the elevation exceeds about $3000 \mathrm{~m}$. This observation suggests that the granitic rocks occurring around the Chur and Kainchwa peaks are not diapiric intrusions into the Jutogh metasediments but are the erosional remnants of one larger subhorizontal sheet-like granite body.

\subsection{Contact relation}

The contact between the granite and the surrounding Jutogh mica schist in the Chur area is razor-sharp wherever exposed and can be very precisely located in the field. The contact and the foliation in both the granite and the adjacent mica schist are all strictly

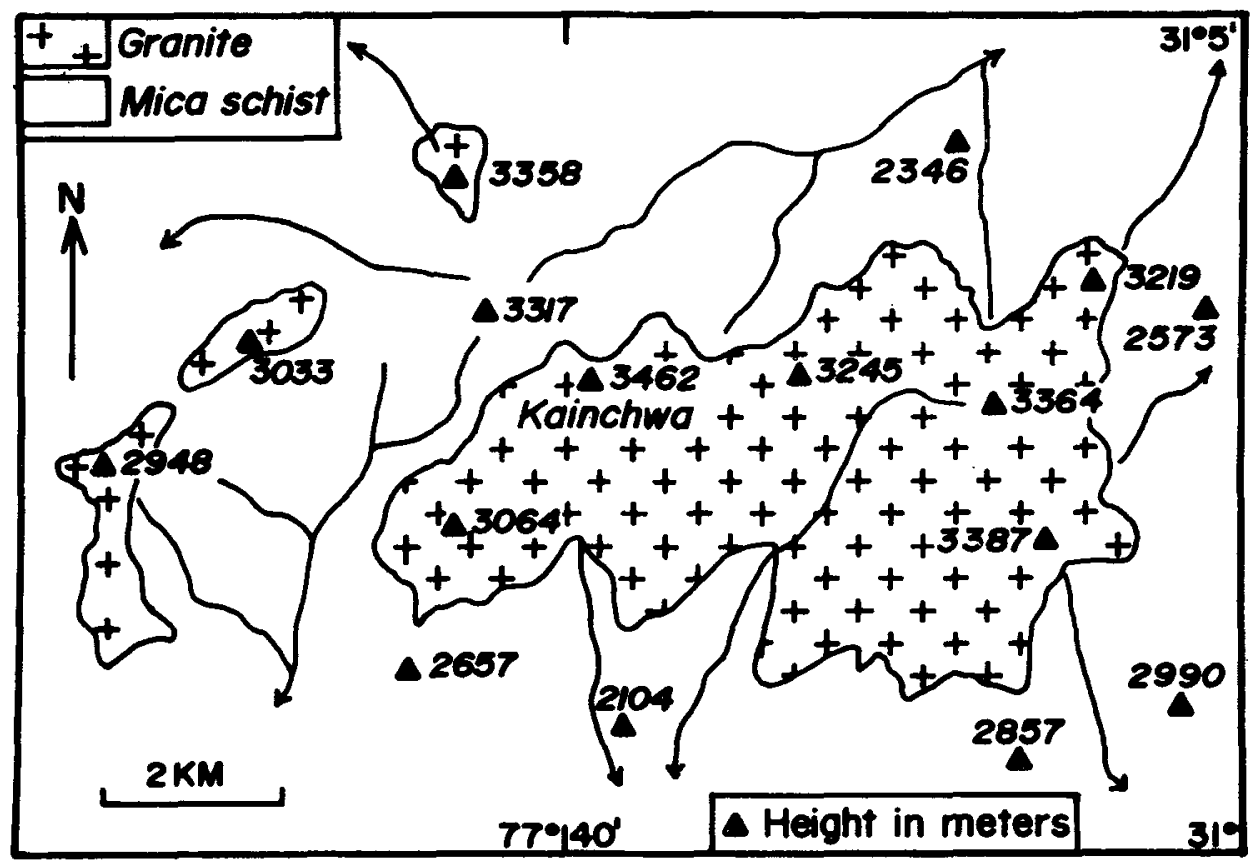

Figure 4. Geological map of the area around the Kainchwa peaks, NE of the Chur area showing small isolated outcrops of granite occupying the highest topographic levels (modified after Srikantia and Bhargava 1988). The topography is indicated by drainage pattern and altitude of peaks. 
parallel. Elsewhere, thin slices of granite in mica schist and thin mica schist slices in granite have been observed. These slices with thickness never more than a few tens of $\mathrm{cm}$ are restricted near the contact and are strictly parallel to the adjacent foliation planes. In order to check the contact relation, about twelve $\mathrm{km}$ of the granite contact was mapped in detail between Chogtali and Chauras southwest of the Chur peak (figure 5). This area was chosen particularly because the dip of the contact varies from gentle near Chogtali to rather steep near Chauras. Nowhere were any cross-cutting relationship or apophysis ever been observed from outcrop to map scales. Irrespective of the amount of dip, the contact is always conformable with the local foliation planes. Stereographic plot of foliation planes measured near the contact, however, shows folding on a gentle easterly plunging open fold which explains the variation in the amount of dips (figure 5). The stretching lineations in this area have a gentle plunge towards NE. Close to the contact in both the rocks, a large number of pegmatite and quartz veins are usually present but they disappear within a short distance from the contact. Some of the pegmatite veins contain xenoliths of granite. These veins often cross cut the foliation surfaces. Where veins are profusely developed it may erroneously be interpreted that the granite has an intrusive relation with the mica schist. These veins are syn- to late-kinematic with respect to the Tertiary thrusting movements, derived from the surrounding rocks possibly due to shear heating and fluid interaction.

\subsection{Outcrop pattern}

The contact dips gently towards the granite in the southern, eastern and the western parts of the area (figure 3). At some of the places in the northern part the contact dips

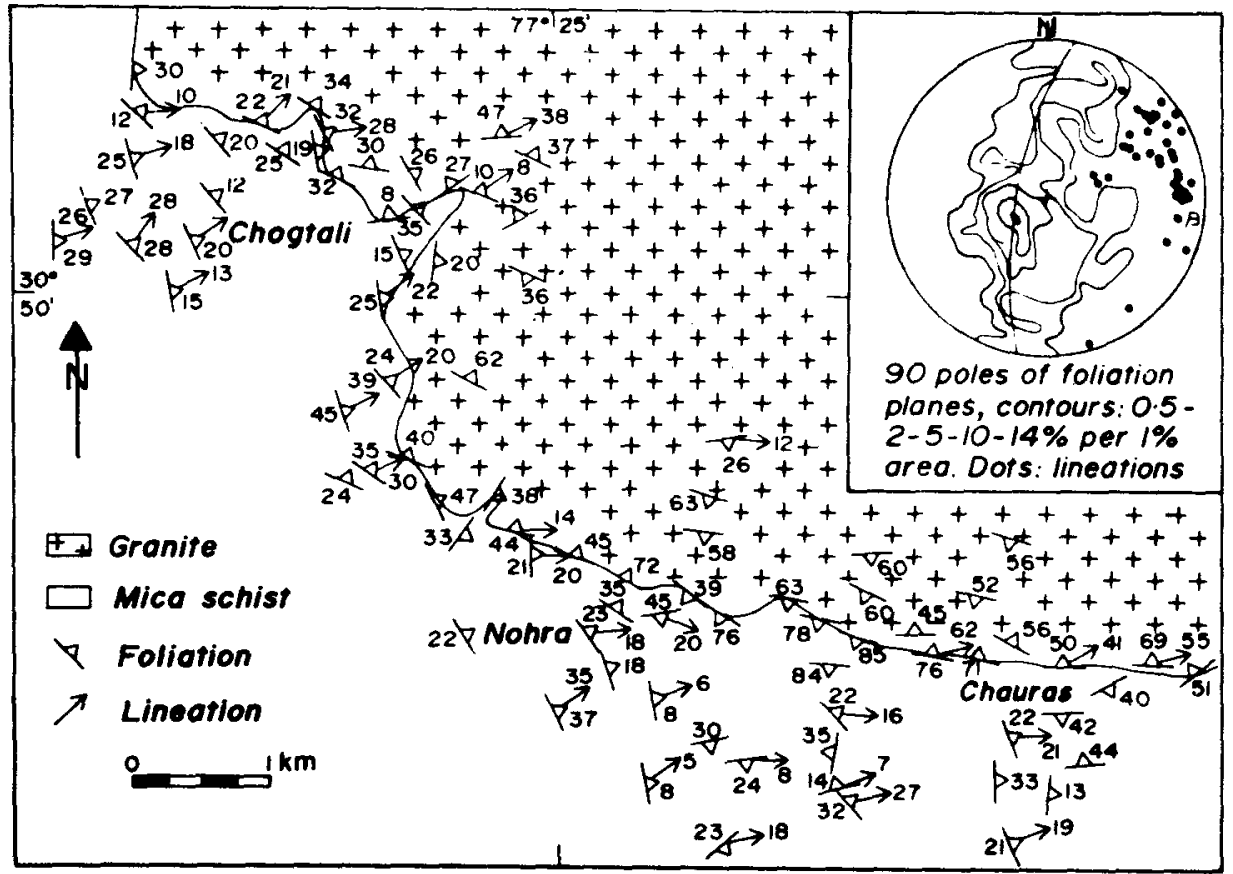

Figure 5. Detailed structural map of the contact between the Chur granite and the Jutogh mica schist in the southwestern part of the area. The inset shows stereographic projection diagram of the mylonitic foliations and stretching lineations. 
away from the granite. This led Pilgrim and West (1928) to conclude that the mica schist overlies and underlies the granite in the north and in the south respectively since in the direction of the dip the overlying rocks should be exposed. The occurrence of garnet near the Chur peak was taken to indicate the presence of mica schist outcrops. Therefore, Pilgrim and West (1928) suggested that the granite is a laccolithic intrusion into the Jutogh mica schist. Kanwar and Singh (1979) suggested that this laccolithic intrusion took place along the core of a huge isoclinal fold with gentle dip of axial plane. However, in the north, the direction of slope and the dip direction are same (i.e., towards north) in some of the places but the slope is steeper than the amount of dip. With this relationship the underlying rocks should be exposed in the direction of the dip of the contact. Further, thin section studies show that the garnet-bearing rocks near the Chur peak are granites and not mica schist. Finally, if the contact is isoclinally folded with gently dipping axial plane (Kanwar and Singh 1979) then the contact and the $s$-surfacesshould have rotated through vertical at some places which is not the case here. Therefore, the granite everywhere overlies the Jutogh mica schist and the postulates of Pilgrim and West (1928) and Kanwar and Singh (1979) are clearly not tenable.

The closed outcrop pattern indicates that it is the same contact everywhere. In a major part the contact as well as the concordant cleavage planes in both the granite and mica schist dip gently towards the granite (figure 3). Therefore, the contact has an overall shallow basin type of configuration. This, together with the topography which slopes away in all directions rather steeply from the area around the Chur peak, readily explains the closed outcrop pattern of the granite. Locally, dip of the contact becomes steeper and at some places in the northeastern part the dip direction is away from the granite body. This is due to the late stage gently plunging upright folding as well as due to thrust related folding. The upper contact of the granite is not exposed in this area.

\section{$2.5 K$-feldspar megacrysts}

The granite is massive in most part but is strongly foliated near the margin. In the massive granite, very large (occasionally exceeding $15 \mathrm{~cm}$ in length) $\mathrm{K}$-feldspar megacrysts occur in a coarse-grained matrix consisting of quartz, K-feldspar, plagioclase, biotite, muscovite, epidote, sphene, \pm garnet, \pm kyanite and \pm sillimanite. The megacrysts constitute as much as $20-30 \%$ of the volume and occur as randomly oriented, nearly perfect rectangular crystals that impart a typical porphyritic texture to the rocks in outcrops (figure 6a). Except for some undulose extinction and rare marginal granulation the megacrysts are virtually undeformed. The granite body is massive in most part but is strongly foliated near the margin. Nearer to the contact with the Jutogh mica schist a foliation gradually becomes very prominent (figures $6 \mathrm{~b}$ and $\mathrm{c}$ ). Concomitant with the development of the foliation the K-feldspar megacrysts are broken into smaller fragments, become lensoid-shaped (or 'augen'-like) and the long dimensions show strong preferred orientation (figures $6 \mathrm{~b}$ and $\mathrm{c}$ ). Figure 7 shows that as the degree of development of foliation increases the long dimensions of the megacrysts gradually become parallel to the foliation planes and the ratio between the long and the short axes assumes a well-defined and higher value. This variation in size, shape and orientation is perfectly gradational from unfoliated granite occurring towards the center to the well-foliated margin. 


\subsection{Mylonitization of the Chur granite}

It has been mentioned earlier that much of the granite body is massive and does not show any evidence of deformation. Only near the contact with the mica schist the granite is strongly foliated. The gradation from massive to foliated granite is perfectly gradual. The thickness of the foliated zone near the margin varies from a few meters to more than a hundred meters. Consequently, the outcrop width of the foliated granite also varies widely. However, the massive granite in the central part has also been foliated in discrete zones of limited width and length but they are insignificant in areal extent.

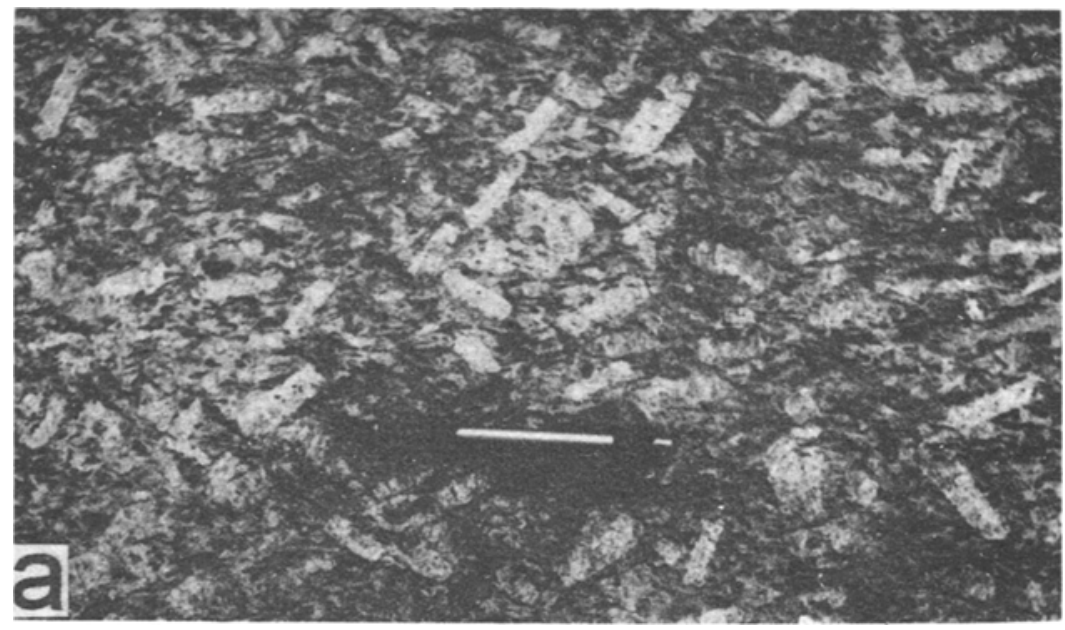

Figure 6(a). Undeformed granite showing the large, rectangular and randomly oriented $\mathrm{K}$-feldspar megacrysts imparting the rock a typical porphyritic texture.

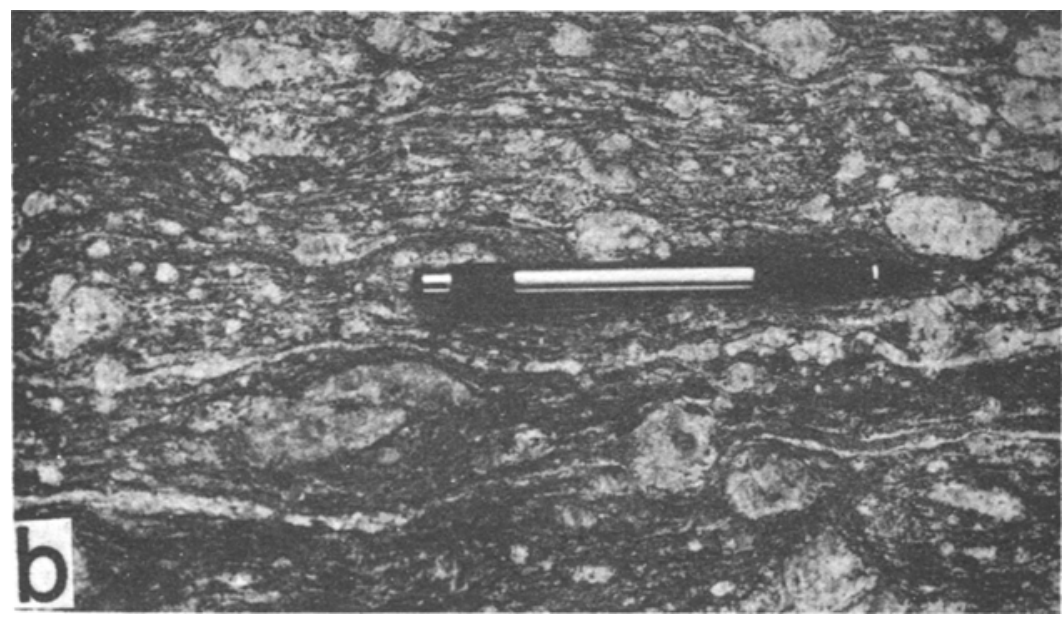

Figure 6(b). Moderately deformed granite showing preferred orientations of K-feldspar megacrysts and mylonitic foliation giving the rock an appearance of augen gneiss. 


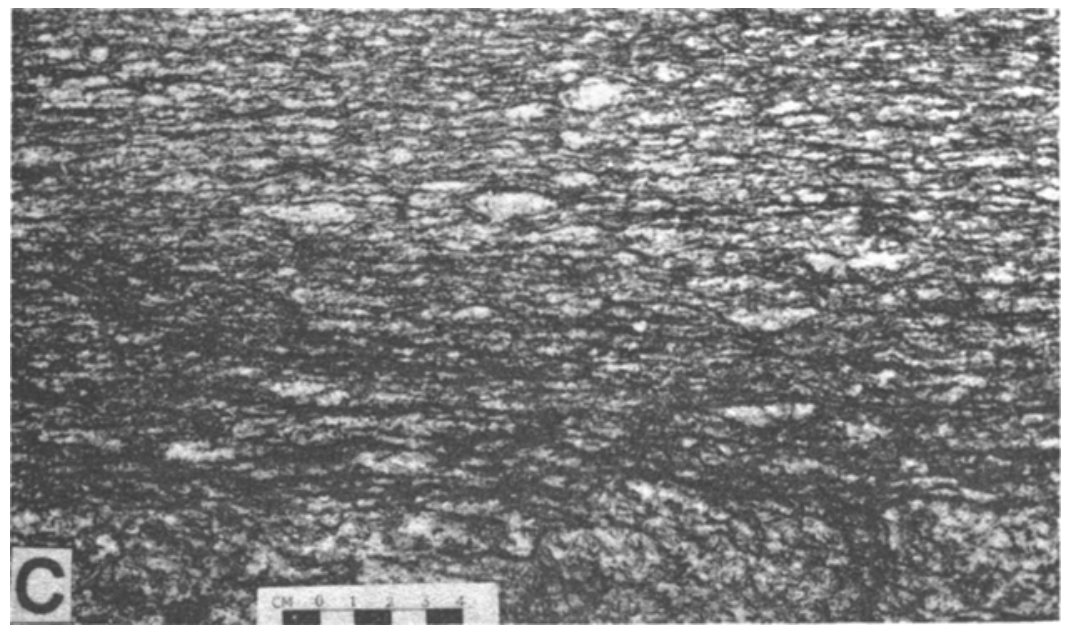

Figure 6(c). Intensely deformed granite near the contact. Note that the mylonitic foliation is very well-developed and the megacrysts are virtually obliterated.

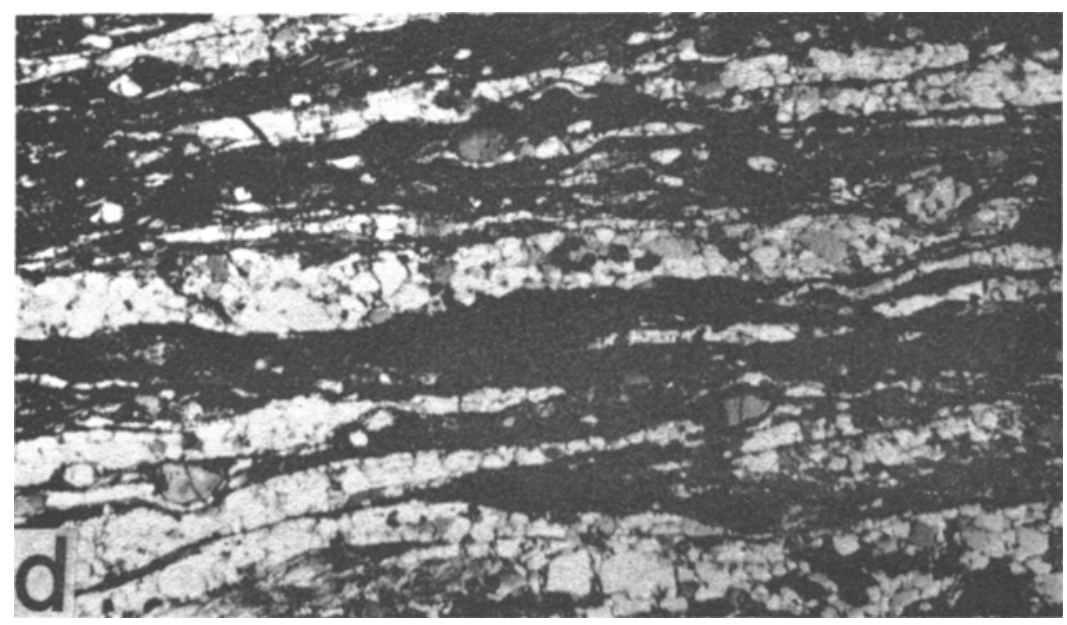

Figure 6(d). Thin section of a granite mylonite with mylonitic foliation traced by very long recrystallized quartz ribbons. The dark portions are rich in micas. Crossed nicols base: $5.2 \mathrm{~mm}$.

Towards the center where the granite is massive or weakly foliated, anomalous extinction, kinked and bent cleavage traces in micas and twin lamellae in feldspars and development of small recrystallized grains at the boundaries of larger grains (mortar texture) are the characteristic features in thin sections. This grades into rocks where highly strained surviving megacrysts occur in a matrix consisting of fine-grained recrystallized, polygonal and strain-free grains. This in turn grades into rocks where surviving megacrysts are few in number and a very well-developed foliation is traced by long and recrystallized quartz ribbons (figure $6 \mathrm{~d}$ ). The mica grains are broken into smaller grains and are smeared along the foliation planes. They also form ribbons and are recrystallized at places. The K-feldspar megacrysts invariably show core-and-mantle texture. 

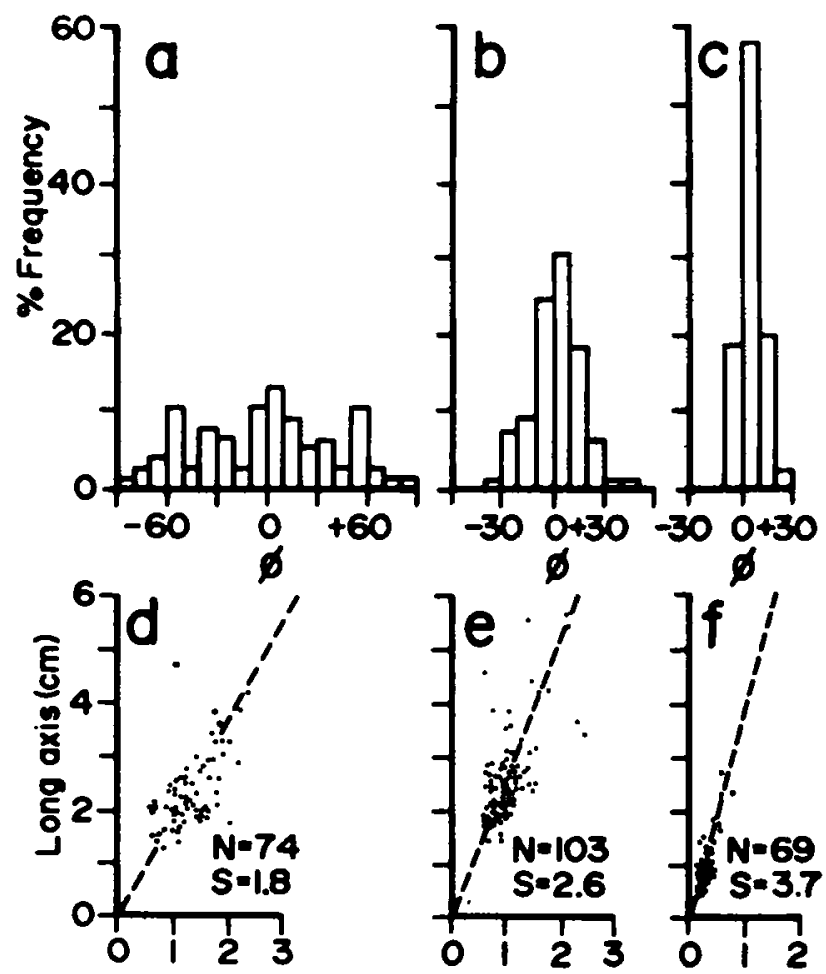

Short axis (cm)

Figure 7. Histograms (a-c) of the angle ( $\phi$, clockwise positive) between the long axis of K-feldspar megacrysts in granite measured with reference to mylonitic foliation (arbitrary reference direction in a) and long axis vs. short axis plots ( $\mathbf{d}-\mathbf{f})$ for the same porphyroclasts. (a,d): Undeformed granite. (b, e): Moderately deformed granite. (c, n): Highly deformed granite. N: number of data, S: slope.

Grain-size reduction via dynamic recrystallization and neomineralization is the most characteristic feature in the foliated granite. All these lines of evidence prove beyond doubt that the foliated granite at the margin (figure 6c) is nothing but a mylonitized granite (cf., Bell and Etheridge 1973; Hobbs et al 1976; White et al 1980). The mylonitization varies from protomylonite through mylonite to ultramylonite sometimes even in a single thin section (cf., Wise et al 1984). In outcrops and in thin sections it is clear that the foliation is undoubtedly mylonitic and not flow banding (Pilgrim and West 1928) or gneissosity (Kanwar and Singh 1979). In highly deformed rocks mylonitic foliation traced by quartz ribbons and aligned micas often wrap around relict lensoid K-feldspar megacrysts. The deformed, lensoid-shaped K-feldspar megacrysts are confined to the mylonitized zone near the contact with the surrounding mica schist and together with the mylonitic foliation the rock has an appearance of a typical 'augen gneiss'. In thin sections and in outcrops S-C fabric (Berthe et al 1979) is quite common. However, it is important to note that the anastomosing mylonite foliation around K-feldspar megacrysts has the appearance of S-C fabric and may lead to erroneous interpretation. Since the variation in the intensity of development of the mylonitic foliation and also the variation in mylonite microstructures are gradual in space, it can 
be concluded that the foliated granite near the margin is the deformed and mylonitized part of the granite seen towards the center. The postulation of Kishore and Kanwar (1984) and Choubey et al (1994) that the foliated and unfoliated granites are the two different intrusive phases is clearly not correct.

The underlying mica schist near the contact is also highly mylonitized with a very well-developed mylonitic foliation. The ultramylonites without any surviving $\mathrm{K}$ feldspar megacrysts near the contact are sometimes indistinguishable from the mica schist in outcrops and the contact deceptively appears to be gradational. It is interesting to note that gradational contacts have been suggested for some of the Lesser Himalayan granites.

\subsection{Metamorphism}

There is no contact metamorphic effect in the mica schist even at the contact. The mica schist adjacent to the granite contains staurolite, kyanite and sillimanite. Neither. texture nor mineral assemblage typical of contact metamorphism has ever been found. Hornfelsic texture, reported (but not documented) by Das and Rastogi (1978) from the mica schist near the contact with the granite is not present. At some of the outcrops mica schist has clots of micas giving the appearance of spotted schist. Detailed thin section studies show that this texture is a result of disruption of differentiated crenulation cleavage due to shearing at an angle to the differentiated layering (Mukhopadhyay et al in press). This area shows the classic inverted metamorphic zonation with the grade of metamorphism increasing towards higher topographic/structural levels and towards the granite. Detailed petrographic and microstructural studies in the metasedimentary rocks of the Jutogh Group have shown that the main metamorphic minerals are pre-tectonic with respect to the development of the mylonitic foliation. Finally, geothermobarometric studies (manuscript in preparation) show that there is no systematic increase in temperature of metamorphism in the metasediments from Jutogh thrust to the granite contact. It is interesting to note that inverted metamorphic zones are also present adjacent to some other Lesser Himalaya granites where the granites occur above the highest grade rocks (e.g., Le Fort et al 1980).

\section{Discussion}

\subsection{The mode of emplacement of the Chur granite}

The characteristic features of the Chur granite can be summarized as follows:

- It is an erosional remnant of a large subhorizontal sheet-like body.

- It occurs at the highest topographic levels as well as at the highest tectonic levels and is underlain by several thin subhorizontal thrust sheets composed of metasedimentary rocks.

- The central portion of the granite body is massive, porphyritic with large K-feldspar megacrysts and is largely undeformed.

- Near the contact with the surrounding mica schist the granite shows all the features of a typical mylonite with a well-developed mylonitic foliation. The underlying mica schist is also highly mylonitized and shows strongly developed mylonitic foliation. 
- The variation from undeformed granite in the central part to granite mylonite near the margin is gradual.

- The deformed and lensoid-shaped K-feldspar megacrysts along with well-developed mylonitic foliation imparts the granite an appearance of a typical augen-gneiss.

- The contact of the granite is everywhere concordant with the gently-dipping mylonitic foliation present in both the granite and the underlying mica schist.

- Neither any cross-cutting relationship nor any effect of contact metamorphism is present.

All these lines of evidence taken together prove that the Chur granite is a thrust sheet and not an intrusion, either diapiric or laccolithic, into the surrounding mica schist belonging to the HHCZ. It would be too much of a coincidence for the gently-dipping and very sharp contact to be strictly parallel to the mylonitic foliation and yet the granite to be an intrusion into the mica schist either at its present position or at the pre-thrusting location of the Jutogh Group. The contact relations also do not support the contention of Choubey et al (1994) that the Chur granite has formed by partial melting of the surrounding Jutogh metasediments. Of course the Chur granite must have intruded somewhere into some rocks during the Paleozoic (or Proterozoic, see Singh et al 1994) time, the probable age of this granite. But this cannot be determined now. This thrust sheet was of much larger areal extent but now occurs as small and isolated bodies around the Chur and Kainchwa peaks owing to deep erosion. We have named the thrust at the base of the Chur granite as the Chur thrust (Bhadra et al 1993; Mukhopadhyay et al 1994). Recently, on the basis of the mylonitization of the Chur granite near the contact Singh and Jain (1996) arrived at a similar conclusion. The Chur thrust along with the Chail, the Jutogh and the Rajgarh thrusts cut up the rocks into four thin thrust slices in the frontal part of the HHCZ (the so-called MCT Zone, e.g., Arita 1983) in this area. We have not used S-C fabric in the granite mylonites to determine the sense tectonic transport of the Chur granite. This is because, as mentioned earlier, the anastomosing mylonitic foliation around $\mathrm{K}$-feldspar megacrysts have the appearance of S-C fabric and may lead to error. However, $\mathrm{S}-\mathrm{C}$ fabric in the carbonaceous schist at the Rajgarh and Jutogh thrusts gives consistent top-to-SW sense of movement (Mukhopadhyay et al submitted). It is reasonable to assume the same sense of movement for the Chur thrust also.

\subsection{Regional extension of the Chur thrust}

The granite bodies around the Kainchwa peak (figure 1b) have the same geologic and tectonic settings as the Chur granite (Srikantia and Bhargava 1988). We may, therefore, extend the Chur thrust up to this area. Further extension of the Chur thrust towards $\mathrm{E}$ or $\mathrm{W}$ and northward into the Higher Himalaya can only be speculative at present.

Many of the granites and the augen-gneisses in the Lesser Himalaya belt (figure 1a) are similar to the Chur granite in their structural setting, petrography and field relations (for reviews see Valdiya 1980; Thakur 1983). Most of them are porphyritic in the central part but become (augen) gneissic near the margin and occur as gentlydipping concordant sheet-like bodies. A small granite body (the Lansdowne granite, Ls in figure 1a) of about $10 \mathrm{~km}^{2}$ in areal extent has been suggested to have a thrust contact with the underlying HHCZ rocks (Gupta 1976). Further, some of the concordant augen 
gneisses are clearly granite mylonite (e.g., Gururajan 1990). Therefore, it seems likely that some or even a majority of the granites and augen gneisses occurring in the Lesser Himalaya belt are thrust slices although an intrusive relation with the country rocks for a few of them cannot be completely ruled out. This suggestion is not novel (see Stocklin 1980; Sinha-Roy and Sengupta 1986) but we advocate that these granites and augen gneisses need to be mapped in detail and their contact relations should be re-examined as in general they have been interpreted to be laccolithic/sheet intrusions in to the metasedimentary country rocks.

\section{Conclusions}

- Several lines of evidence prove that the granite occurring around the Chur (or Chor) peak in the Lesser Himachal Himalaya represents a thrust sheet.

- Many of the granites and the granitic augen gneisses occurring in the Lesser Himalaya have similar contact relations as that of the Chur granite. Therefore, at least some of them could also be thrust sheets.

\section{Acknowledgements}

Our work was supported by the C.S.I.R. (Govt. of India) grant nos. 24/189/88/EMR-II and 24(0219)/93/EMR-II. Our thanks are due to Prof, K Naha and Dr. M S Pandian for reviews on an earlier draft of the manuscript. We are grateful to Prof. and Mrs. S K Kaushik for providing logistic facilities during fieldwork.

\section{References}

Arita K 1983 Origin of the inverted metamorphism of the Lower Himalayas, Central Nepal; Tectonophysics $9542-60$

Bell T H and Etheridge M A 1973 Microstructure of mylonites and their descriptive terminology; Lithos 6 337-348

Berthe D, Choukroune P and Jegouzo P 1979 Orthogneiss, mylonite and noncoaxial deformation of granites: The example of the South Armorican Shear Zone; J. Struct. Geol $131-42$

Bhadra B K, Ghosh T K, Srivastava D C and Mukhopadhyay D K 1993 Thrust imbrication in the Jutogh series and the status of the Chur granite, southeast of the Simla Hills, Himachal Pradesh; Seminar on Himalayan Geology and Geophysics (New Data and New Approaches), Wadia Institute of Himalayan Geology, Dehra Dun, India, Abstract Volume, 17

Chatterji G C and Swami Nath J 1977 The stratigraphy and structure of parts of the Simla Himalaya - A synthesis; Mem. Geol. Surv. India $106408-498$

Choubey V M, Sharma K K and Rameshwar Rao D 1994 Crustal anatexis and petrogenesis of the granitoid rocks, Chor region, Himachal Himalaya; J. Himalayan Geol. 5 1-9

Das B K and Rastogi R 1978 Evidence of contact metamorphism in the Chor area, Himachal Pradesh; Curr. Sci. 47 861-862

Deniel C, Vidal P, Fernandez A, Le Fort P and Peucat J-J 1987 Isotopic study of the Manaslu granite (Himalaya, Nepal): Inferences on the age and source of Himalayan leucogranites; Contrib. Mineral. Petrol. 96 78-92

Dietrich V and Gansser A 1981 The leucogranites of the Bhutan Himalaya (Crustal anatexis versus mantle melting); Schw. Mineral. Petrogr. Mitt. 61 177-202

Fuchs G 1981 Outline of the geology of the Himalaya; Mitt. Osterr. Geol. Ges. 74/75 101-127 
Gansser A 1964 Geology of the Himalaya (New York: Interscience)

Gupta N L 1976 A contribution to the geology of Lansdowne area, Garhwal Himalayas, India, J. Geol. Soc. India $17449-460$

Gururajan N S 1990 Deformation microstructures and geochemistry of the mylonitic augen gneisses in the Chail thrust zone in Satluj valley of Himachal Pradesh; J. Geol. Soc. India 36 290-306

Heim A and Gansser A 1939 Central Himalaya. Geological observations of the Swiss expedition 1939; Mem. Soc. Helv. Sci. Nat. 73 1-245 (Reprinted by Hindustan Publishing Corporation, New Delhi, 1975)

Hobbs B E, Means W D and Williams P F 1976 Outline of structural geology (New York: Wiley and Sons)

Kanwar R C and Singh I 1979 Structural history of the Jutogh metasediments, SW of Chur mountain, Sirmur district, Himachal Pradesh; In: Structural Geology of the Himalaya (ed) P S Saklani (New Delhi: Today and Tomorrow's Publishers) pp. 183-200

Kishore N and Kanwar R C 1984 Petrography, petrochemistry, origin and emplacement of Chor granites; Bull. Indian Geol. Assoc. 17 1-27

Le Fort P 1975 Himalayas: the collided range. Present knowledge of the continental arc; Am. J. Sci. A275 1-44

Le Fort P 1981 Manaslu leucogranite: A collision signature of the Himalaya. A model for its genesis and emplacement; J. Geophys. Res. $8610545-10568$

Le Fort P 1988 Granites in the tectonic evolution of the Himalaya, Karakoram and Southern Tibet; Philos. Trans. R. Soc. London A326 281-299

Le Fort P, Debon F and Sonet J 1980 The 'Lesser Himalayan' cordierite granite belt: Typology and age of the pluton of Manserah (Pakistan); Geol. Bull. Peshwar Univ. (Special Issue) 13 51-61

Mukhopadhyay D K, Bhadra B K, Ghosh T K and Srivastava D C 1994 Thrust imbrication, inverted metamorphism and emplacement of Lesser Himalaya granite around Chur peak, Himachal Himalaya; $J$. Geol. Soc. Nepal 10 (Abstract Volume, 9th Himalaya-Karakoram-Tibet Workshop, Kathmandu) 89-90

Mukhopadhyay D K, Bhadra B K, Ghosh T K and Srivastava D C Development of compressional and extensional structures during progressive ductile shearing. Main Central Thrust Zone, Lesser Himachal Himalaya; In: Evolution of Geologic Structures in Micro- to Macro-scales (ed) S Sengupta (London: Chapman \& Hall) (in press)

Mukhopadhyay D K, Bhadra B K, Ghosh T K and Srivastava D C Ductile shearing and large-scale thrust imbrication in the Main Central Thrust Zone, Chur-peak area, Lesser Himachal Himalaya; J. Geol. Soc. India (submitted)

Naha K and Ray S K 1971 Evidence of overthrusting in the metamorphic terrane of the Simla Himalayas; Am. J. Sci. $27030-42$

Paul S K 1990 Geological map of the western Himalaya (Dehra Dun: Surya Publications)

Pecher A and Le Fort P 1977 Origin and significance of the Lesser Himalaya augen gneisses; Ecol. Geol. Him., CNRS Paris 268 319-329

Pilgrim G E and West W D 1928 The structure and correlation of the Simla rocks; Mem. Geol. Surv. India 53 $1-150$

Scharer U and Allegre C J 1983 The Palung granite (Himalaya); high-resolution U-Pb systematics in zircon and monazite; Earth Planet. Sci. Lett. 63 423-432

Singh S, Claesson S, Jain A K, Sjoberg H, Gee D G, Manickavasagam R and Andreasson P G 1994 Geochemistry of the Proterozoic peraluminous granitoids from the Higher Himalaya Crystalline (HHC) and Jutogh nappe, NW-Himalaya, Himachal Pradesh India; J. Geol. Soc. Nepal 10 (Abstract Volume, 9th Himalaya-Karakoram-Tibet Workshop, Kathmandu) 125

Singh S and Jain A K 1996 Ductile shearing of the Proterozoic Chor granitoid in the Lesser Himalaya and its significance; J. Geol. Soc. India 47 133-137

Sinha-Roy S and Sengupta S 1986 Precambrian deformed granites of possible basement in the Himalayas; Precamb. Res. 31 209-235

Srikantia S V and Bhargava O N 1988 The Jutogh Group of metasediments of the Himachal Himalaya: Its lithostratigraphy; J. Geol. Soc. India 32 274-279

Stocklin J 1980 Geology of Nepal and its regional frame; J. Geol. Soc. London 137 1-34

Thakur V C 1981 An overview of the thrusts and nappes of western Himalaya; In: Thrust and Nappe Tectonics (eds) K R McClay and N J Prince, J. Geol. Soc. London (Spl. Publ.) 9 381-392

Thakur V C 1983 Granites of western Himalayas and Karakorum - structural framework, geochronology and tectonics; In: Granites of Himalayas, Karakorum and Hindu Kush (ed) F A Shams (Institute of Geology, Punjab University, Lahore, Pakistan) pp. 327-339

Trivedi J R, Gopalan K and Valdiya K S $1984 \mathrm{Rb}-\mathrm{Sr}$ ages of granitic rocks within the Lesser Himalayan Nappes, Kumaun, India; J. Geol. Soc. India 25 641-654 
Valdiya K S 1980 Geology of Kumaun Lesser Himalaya (Dehra Dun, India: Wadia Institute of Himalayan Geology)

Virdi N S 1979 Status of the Chail Formation vis-a-vis Jutogh-Chail relationship in the Himachal Lesser Himalaya; Him. Geol. 9 111-125

White S H, Burrows S E, Carreras J, Shaw N D and Humphreys F J 1980 On mylonites in ductile shear zones; J. Struct. Geol. 2 175-187

Wise D U, Dunn D E, Engelder J T, Geiser P A, Hatcher R D, Kish S A, Odom A L and Schamel S 1984 Fault-related rocks: Suggestions for terminology; Geology 12 391-394 